Maurer School of Law: Indiana University

\title{
Stock Dividends as Taxable Income
}

Follow this and additional works at: https://www.repository.law.indiana.edu/ilj

Part of the Securities Law Commons, and the Tax Law Commons

\section{Recommended Citation}

(1937) "Stock Dividends as Taxable Income," Indiana Law Journal: Vol. 12 : Iss. 3 , Article 8.

Available at: https://www.repository.law.indiana.edu/ilj/vol12/iss3/8

This Note is brought to you for free and open access by the Law School Journals at Digital Repository @ Maurer Law. It has been accepted for inclusion in Indiana Law Journal by an authorized editor of Digital Repository @ Maurer Law. For more information, please contact rvaughan@indiana.edu.

\section{$\Psi$}

JEROME HALL LAW LIBRARY

INDIANA UNIVERSITY

Maurer School of Law
Bloomington 
Stock Divrdends as Taxable Income.-In 1924 and 1926 the petitioner purchased cumulative nonvoting preferred stock of Columbia Steel Corporation. The company's articles of incorporation provided that holders of preferred stock should receive an annual dividend of $\$ 7$ a share or, at the company's option, one share of common stock for each share of preferred. The common stock had voting rights; and upon dissolution it was entitled to all the assets remaining after payment of the preferred, at par, and accrued dividends thereon. From 1925 to 1928 the company elected to pay the preferred shareholders dividends in common stock, although it had a surplus sufficient to pay them in cash. The company redeemed the preferred stock in 1930; and the commissioner, in computing petitioner's profit, apportioned the cost of the preferred stock between the preferred and the common stock received as dividends in proportion to their respective values, thereby decreasing the cost basis per share and increasing the gain. Held, dividends on cumulative nonvoting preferred shares paid in common voting shares were "income" and not "returns from capital"; and consequently, the cost of the preferred shares cannot be apportioned between the preferred and the common shares for determining the gain on the preferred shares.1

After the adoption of the Sixteenth Amendment and the passage of the Revenue Act of 1913, imposing income tax on dividends, 2 the question naturally arose as to whether or not stock dividends were taxable as income. In the leading case 3 on the question, the Supreme Court held that dividends on common stock in the form of common stock were not income within the meaning of the Sixteenth Amendment, hence not directly taxable as such. However, it should be noted that such dividends are not entirely exempt from income tax, since they are taxed upon sale to the extent that the proceeds represent a gain over the cost. Nor can the income tax be avoided by the

7 People v. Hecht (1931), - Cal. -, 3 Pac. (2d) 399; DeFlorin v. State (1905), 121 Ga. 593, 49 S. E. 699; People v. Wassmus (1921), 214 Mich. 42, 182 N. W. 66; People v. McPhee (1905), 139 Mich. 687, 103 N. W. 174; State v. Wolford (1921), - Minn. -, 185 N. W. 1017. See also: State v. Emerson (1927), - Mo. -, 1 S. W. (2d) 109; State v. Lipkin (1915), 169 N. C. 265,84 S. E. 340 .

8 Thomas v. People (1871), 59 Ill. 160; Negley v. Delvin (1872), 12 Abb. Prac. (N. S.) 210 (N. Y.).

9 Lohman v. State (18S1), 81 Ind. 15; Hudelson v. State (1883), 94 Ind. 426; Utz v. Wolf (1920), 72 Ind. App. 572, 126 N. E. 327; Standridge v. Williford-Burns-Rice Co. (1918), 148 Ga. 283, 96 S. E. 498; Glover v. Malloska (1927), 238 Mich. 216, 213 N. W. 107; State v. Powell (1927), 170 Minn. 239, 212 N. W. 169; Retail Section Chamber of Commerce of Plattsmouth v. Kieck (1934), - Neb. -, 257 N. W. 493 ; Carl Co. v. Lennon (1914), 148 N. Y. S. 375; Market Plumbing \& Heating Supp. Co. v. Spagenberger (1934), 112 N. J. Law 46, 169 Atl. 660 ; Rountree v. Ingle (1913), 94 S. C. 231,77 S. E. 931; Featherstone v. Independent Service Station Ass'n of Texas (1928), - Tex. $10 \mathrm{~S}$. W. (2d) 124. See also: Waite v. Press Publishing Ass'n (1907), 155 Fed. 58 (Dist. Mich.); United States v. Wallis (1893), 58 Fed. 942 (Dist. Idaho); State v. Mumford (1881), 73 Mo. 647; Blair v. Lowham (1929), - Utah -, 276 Pac. 292. See: 48 A. L. R. 1115; 57 A. L. R. 424.

1 Koshland v. Helvering (1936), 56 Sup. Ct. 767, reversing 81 Fed. (2d) 641.

238 Stat. 166, 167. For the present act, see 26 U. S. C. A. 22 and 26 U. S. C. A. 115 .

3 Eisner v. Macomber (1920), 252 U. S. 189, 64 L. Ed. 521. See, also, Towne v. Eisner (1918), 245 U. S. 418, 62 L. Ed. 372. 
distribution of a nontaxable stock dividend, which is promptly redeemed in cash $;^{4}$ this is held to be essentially a cash dividend.5

The leading case ${ }^{6}$ established two tests for distinguishing a taxable from a nontaxable dividend in stock: (1) Severance of assets from the corporation, and (2) alteration of pre-existing proportionate interest of the stockholders. In dealing with subsequent cases involving stock dividends of various kinds, the courts have considered the substance of the transaction and have not given full effect to the broad language used in that case; however, the tests set out in that decision are often the very basis for the result reached. Thus where a stockholder received a dividend consisting of stock in a newly formed foreign corporation, which dividend represented his proportionate share of the surplus, it was held that the dividend was income, because there was a severance of treasury assets from the corporation and the interests of the stockholders were necessarily changed, since the new corporation was formed under the laws of another state, which, of itself, imports a change in the responsibilities and duties of the stockholders.7 Similar holdings were had in analogous reorganization cases. 8 Applying the same tests, the court has held that there was no gain where the stockholders in return for their stock receive stock of another corporation of the same state, which stock does not change their proportionate interest or control in the business.9 A holder of voting common stock was held to have received no income by the declaration of a dividend of nonvoting common stock of the same character, since his voting rights, as well as his expectancy in the corporate capital, remained unchanged.10 Likewise, there is no income received where a corporation, having only common stock, issues both common and preferred shares in place of its common stock, for the reason that this results only in a proportionate distribution among existing shareholders of new certificates representing their unchanged interest in the corporation.11 At first glance one might conclude that there was a change of the stockholder's proportionate interest and control here, because he received some preferred stock, whereas before he had only common; but since there was no outstanding preferred stock before the transaction, each shareholder's rights were unaffected by the change, except that each had preferred as well as common shares in the same ratio. What actually happened was that each shareholder received a preference against himself.

After considering the reasoning of the judges in the above cases, one

426 U. S. C. A. 115 (g)

5 Shelby H. Curlee, Trustee (1933), 28 B. T. A. 773; Annie Watts Hill (1932), 27 B. T. A. 73. See, also, Henry B. Babson (1933), 27 B. T. A. 859; Louis Rorimer (1933), 27 B. T. A. 871; T. Pierre Champion (1933), 27 B. 'T. A. 1312.

B Eisner v. Macomber (1920), 252 U. S. 189,64 L. Ed. 521.

7 United States v. Phellis (1921), 257 U. S. 156, 66 L. Ed. 180.

8 Rockefeller v. United States (1921), 257 U. S. 176, 66 L. Ed. 186; Cullinan v. Walker (1923), 262 U. S. 134, 67 L. Ed. 906; Marr v. United States (1925), 268 U. S. 536, 69 L. Ed. 1079.

D Weiss v. Stearn (1924), 265 U. S. 242, 68 L. Ed. 1001.

10 Chapman v. United States (1927), $63 \mathrm{Ct}$. Cl. 106, certiorari denied 275 U. S. 524, 72 L. Ed. 406.

11 Frances Elliott Clark (1933), 28 B. T. A. 1225; Pearl B. Brown, Executrix (1932), 26 B. T. A. 901. 
comes to the conclusion that it is but a short step from them to the case before us. 12 What is the practical difference between a dividend consisting of the stock of a newly formed foreign corporation taking over all the assets of the old corporation 13 and one consisting of a different kind of stock in the same corporation, giving the holder different rights as to capital expectancy and as to voting power? After the stock dividend was issued, the petitioner had different rights as to future dividends, different rights in case of liquidation or dissolution, and he had voting power where he had none before. This was not a situation where every one of the stockholders was affected in the same way and to the same extent; here only the preferred shareholders received the stock dividend. Since the rights of the holders of common stock were not changed in a like manner, it hardly can be contended that the petitioner's interest and control were unchanged. It would seem that if the courts have been sincere in basing their decisions in those cases 14 upon alterations of the pre-existing proportionate interests of the stockholders and severance of assets from the corporation, they should by the same reasoning arrive at the result which was reached here. It is true that this case limits the ambit of the leading case 15 to the issues of fact upon which the adjudication rests; but as a matter of technical logic all these decisions can be reconciled. The court arrived at what seems to be the correct result here, and it successfully distinguished this case from other cases on the subject.

This decision is likely to affect both the taxing statutes and corporate management. Until this case was decided, the Treasury Department had supposed that all stock dividends were nontaxable; and Congress evidently relied upon that interpretation in drafting revenue acts.18 Therefore, it would seem that a probable result of this decision will be that Congress will amend the revenue acts so as to make such stock dividends as are really income taxable upon receipt. In view of the Revenue Act of 1936, imposing high surtaxes on undistributed corporate earnings, 17 this holding should be welcomed by the corporations for it will assure them a means of retaining the surplus capital in the enterprise without having to pay the surtax. Now that they are sure that the courts will hold certain types of stock dividends to be true income, they can issue such a dividend without fear that the surtax will apply. Relying upon this case corporations wishing to expand will issue taxable rather than nontaxable stock dividends; and they probably will strongly contend for the extension of this doctrine to the more doubtful cases.

W I. M.

12 See, also, the analogous case of Commissioner of Internal Revenue v. Tillotson Mfg. Co. (1935), 76 Fed. (2d) 189 (C. C. A. 6th), affirming 27 B. T. A. 913.

13 Marr v. United States (1925), 268 U. S. 536, 69 L. Ed. 1079.

14 In almost every case involving the question of stock dividends as income the court has applied the tests set out in Eisner v. Macomber (1920), 252 U. S. 189, 64 L. Ed. 521. See, for example, Rockefeller v. United States (1921), 257 U. S. 176, 66 L. Ed. 186; United States v. Phellis (1921), 257 U. S. 156, 66 L. Ed. 180 .

15 Eisner v. Macomber (1920), 252 U. S. 189, 64 L. Ed. 521.

16 Section 201 (d) of the Revenue Act of 1921 and all subsequent Revenue Acts provided, "A stock dividend shall not be subject to tax." However, this was repealed by the last Congress. For the new provision, see $26 \mathrm{U}$. S. C. A. 115(f).

1749 Stat. 1655, 26 U. S. C. A. 13a. See, also, 49 Stat. 1674, 26 U. S. C. A. 104 . 